\title{
Effects of Poultry Waste as an Additive in Biogas Production using Cow Dung
}

\author{
Ibrahim Sa'adu ${ }^{1 *}$, Ashiru Hussaini ${ }^{2}$, Muhammad Abdulrahman \\ ${ }^{3}$, Idris Salisu Sani ${ }^{4}$, Hafeez Yusuf Hafez ${ }^{5}$, \\ Jibrin Mohammed ${ }^{6}$ \\ 1, 2, 3,5 \& 6 Department of Physics, \\ Federal University Dutse, \\ P.M.B 7156, \\ Dutse, Jigawa State-Nigeria \\ ${ }^{4}$ Department of Physics, \\ Kano State Polytechnics, \\ Kano State-Nigeria.
}

Email: ibrahimsaadu64@yahoo.com

\begin{abstract}
Globally, there is need for the proper utilization of animal waste products (such as cow dung, poultry waste and so on), which can be used as an alternative source of energy. Herein, the effects of poultry waste as an additive in the production of biogas using substrate (cow dung and poultry waste) and $\mathrm{pH}$ value were investigated. The substrate (cow dung and poultry waste) was prepared via simple dry method. Different set up (1, 2, 3,4 and 5) were designed using local materials (based on the floating drum plant type of digester). The gas produced through an anaerobic digestion method of the different set ups were recorded daily at a fixed time (14 hr) for the periods of 10 days. Set up 2 produced the highest volume of gas $\left(89 \mathrm{~cm}^{3}\right), a \sim 2, \sim 1.1, \sim 1.4$ and $\sim 1.6$-folds enhancement compared with set up 1, 3, 4 and 5, respectively. It observed that the gas produced decrease with an increase of the poultry waste, indicating that poultry waste played significant role in boosting the production of the gas. The $\mathrm{pH}$ of the digester and temperature were kept within $\mathrm{pH}$ optimum range of 6.5-8.0 and mesophilic temperature range $20-40{ }^{\circ} \mathrm{C}$, respectively. Thus, the substrate developed (2:1 ratio) was economical, non-hazardous and environmentally friendly.
\end{abstract}

Keywords: Biogas, Cow dung, Poultry Waste, Anaerobic

\section{INTRODUCTION}

The continuous growth and scarcity of energy is among the factors hampering the industrial growth and economic progress of Nigeria. However, with all fossil resources, the quantity of oil is limited and will not last forever (Ogunwande et al., 2013). This leaves renewable energies showing the biggest potential for securing the availability of energy in the future. The main challenge of the present world is to harness the energy source which is environment friendly and ecologically balanced. This need has forced the world to search for the other alternate source of energy. But unfortunately the new alternative energy 
sources like the solar, hydro, wind etc. require huge economic investment and technical power to operate, which seem to be very difficult for the developing countries like Nigeria (Ahmadu, 2009). Biogas systems are highly friendly to the environment. In fact, the contribution of a methane molecule $\left(\mathrm{CH}_{4}\right)$ to the greenhouse effect is 21 times greater than that of a carbon dioxide molecule. Therefore, burning methane, even though producing $\mathrm{CO}_{2}$, reduces its impact on the environment. The digested slurry coming out of the plant is used for organic fertilizer production. Besides, Bio-digesters can be used to treat municipal waste and survival of intestinal parasites. The prospect of this technology is bright in developing countries like Nigeria. This is because Nigeria is an energy resource rich country in terms of both fossil fuels (such as crude oil, natural gas, coal), and renewable energy resources like solar, wind and biomass (Mshandete and Parawira, 2009). Iwayemi, 2008, express that the Nigerian energy industry on a global scale, is probably one of the most inefficient in meeting the needs of its customers. Energy generation from animal waste will not only provide an alternative and renewable energy, but will help clean up and provide healthy environment (Karki et al, 2005). Poultry waste, cow dung and other waste have been used for biogas production, also a Co-digestion of chicken droppings and cow dung had been reported (Nnabuchi, et. al 2012) but the efficiency of the gas production is low.

Previous studies have reported a minimum amount volume of gas generated, low efficiency and effects of $\mathrm{pH}$ value for efficient production of Biogas (Karki et al, 2005, Nnabuchi, et. al 2012 and Alfa et. al 2014). Herein, we reported the effect of poultry waste as an additive to cow dung and $\mathrm{pH}$ value for efficient biogas generations using different set ups.

\section{MATERIALS AND METHOD}

\section{Materials}

The raw materials used in this work are cow dung and poultry waste. Cow dung and poultry waste were collected from Federal University Dutse farm. The samples were dried and grounded into powder separately known as substrate. The substrate was weight using a digital weighing balance. The fixed drum plant type was used for this study, also 5 litre gallon was used as the digester while $250 \mathrm{~cm}^{3}$ measuring cylinder was used as a gas collector with a rubber horse pipe to connect the digester to the cylinder. Rubber cork screw was used to cover the digester top with grease used as seal to avoid leakage.

\section{Method}

The method adopted in the preparation of the digesters was based on Ajoy Karki's Biogas model with little modification (Karki, 2002). $40 \mathrm{~g}$ of cow dung (substrate) only without poultry waste was mixed with water (a ratio of 1:3) in a beaker using a stirrer known as slurry. The slurry prepared was fed to the digester and the biogas production was observed. Each day before starting the experiment, the digester will be stirred The temperature, $\mathrm{pH}$ value, and the volume of gas produced were recorded at fixed time ( $14 \mathrm{hrs}$ daily) for 10 days. This set up is labelled as set-up 1. A similar trend was adopted for the set-up 2 (40 g cow dung and $20 \mathrm{~g}$ poultry waste), set-up 3 ( $40 \mathrm{~g}$ cow dung and $40 \mathrm{~g}$ poultry waste), set-up 4 (40 g cow dung and $60 \mathrm{~g}$ poultry waste) and set-up 5 (40 g cow dung and $80 \mathrm{~g}$ poultry waste). The gas produced was noticed by the down displacement of the water as shown in Figure 1. 


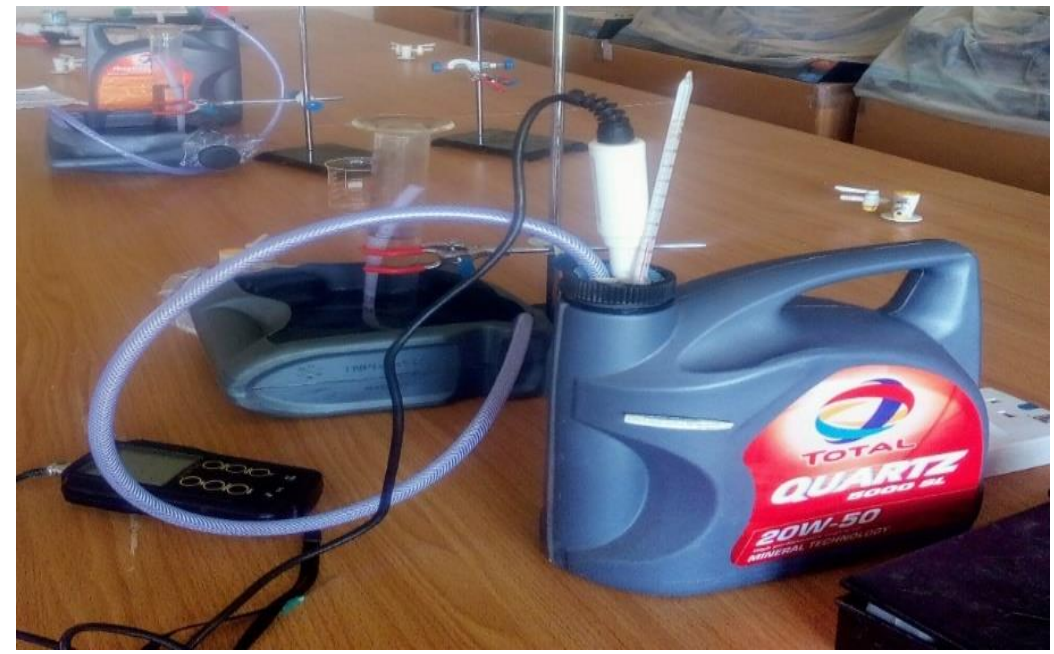

Figure 1 Experimental set up

\section{Determination of Moisture Content (MC)}

The amount of water present in solid waste as percentage wet or dry weight was obtained according to (Hassan, 2015).

$\% M C($ dry wt $)=\frac{a-b}{a} \times 100$

where,

$\mathrm{a}=$ initial weight of sample as measured

$\mathrm{b}=$ weight of sample after drying

$\mathrm{a}-\mathrm{b}=$ weight of moisture content

\section{RESULTS AND DISCUSSION}

\section{Gas produced}

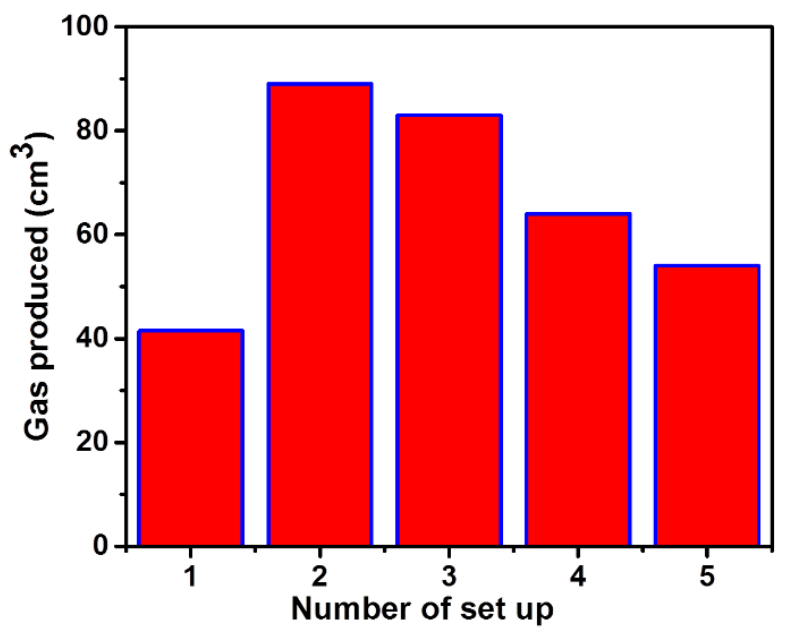

Figure 2. Volume of gas generated for ten days per set up

The cumulative volume of gas generated in different set ups were plotted as shown in Figure 2. The maximum gas produced was observed with the set-up 2. The peak gas produced through anaerobic digestion (AD) is $89 \mathrm{~cm}^{3}$, a $\sim 2, \sim 1.1, \sim 1.4$ and $\sim 1.6$ - times higher than that of set up 1, 3, 4 and 5, respectively. The volume of gas produced in the present study is significantly higher than already reported in the literature. Thus, poultry waste played a vital role in enhancing the production of biogas. This significant improvement can be attributed to the addition of the poultry waste (Nnabuchi, et. al 2012). This result is in agreement with already reported results by Alfa et. al 2014. Therefore, based 
on this result, it shows that for the mixed substrate (cow dung + poultry waste), the gas generation decreases with the increase of the additive substrate.

\section{pH Value}

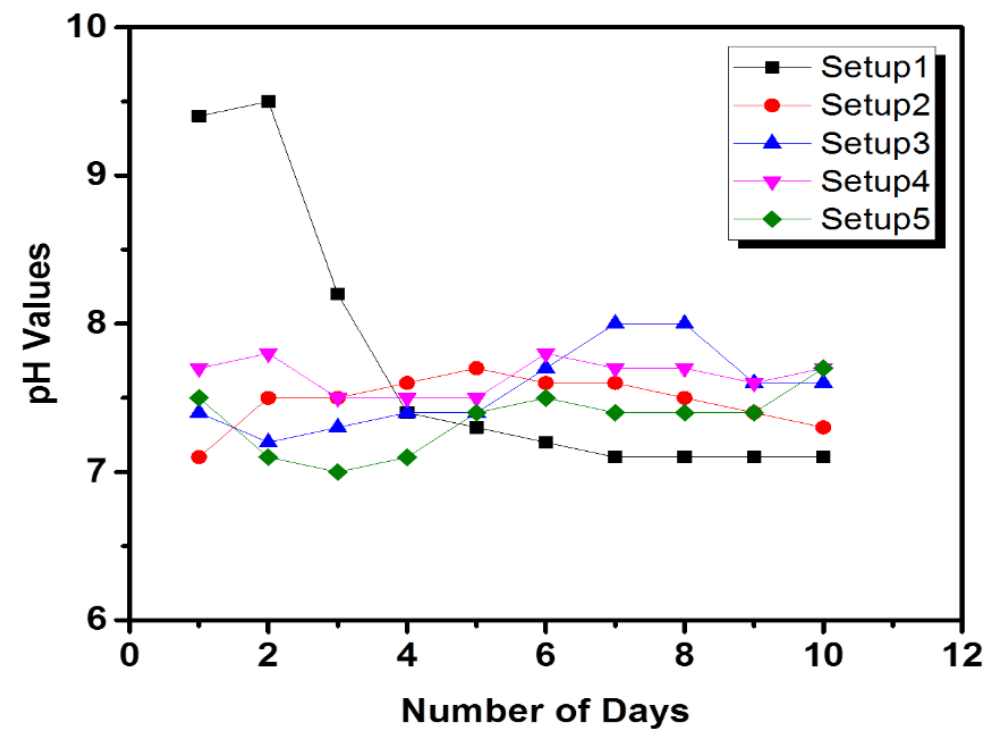

Figure 3 graph of $\mathrm{pH}$ against number of days.

One of important parameter in the anaerobic digestion process that must be observed is $\mathrm{pH}$ value. Rahman and Muyeed (2010) reported that the desirable $\mathrm{pH}$ range for an AD process is 6.5-8.0. Base on the results obtained, the $\mathrm{pH}$ values of the entire samples range from 7.1 to 7.7 throughout the production period. As depicted in Figure 3, the result revealed the $\mathrm{pH}$ ranges of 7.1-7.6, 7.2-8.0, 7.5-7.7 and 7.0-7.5 for set-up 2, set-up 3, set-up 4 and set-up 5, respectively. Although set up 1 exhibit low activity in the $\mathrm{pH}$ range of 7.1- 9.5 and this unusual range can be arising as a result of internal aerobic activity that is taking place in the absence of the poultry waste. According to (Fasoyin, 2019) a good pH is very crucial for the survival of bacteria which help in enabling the biogas production. Therefore, the range of $\mathrm{pH}$ in this study is the desirable $\mathrm{pH}$ range for $\mathrm{AD}$ process which falls within the acceptable range for anaerobic digestion as reported by Abubakar and Ismail, 2012.

\section{Temperature}

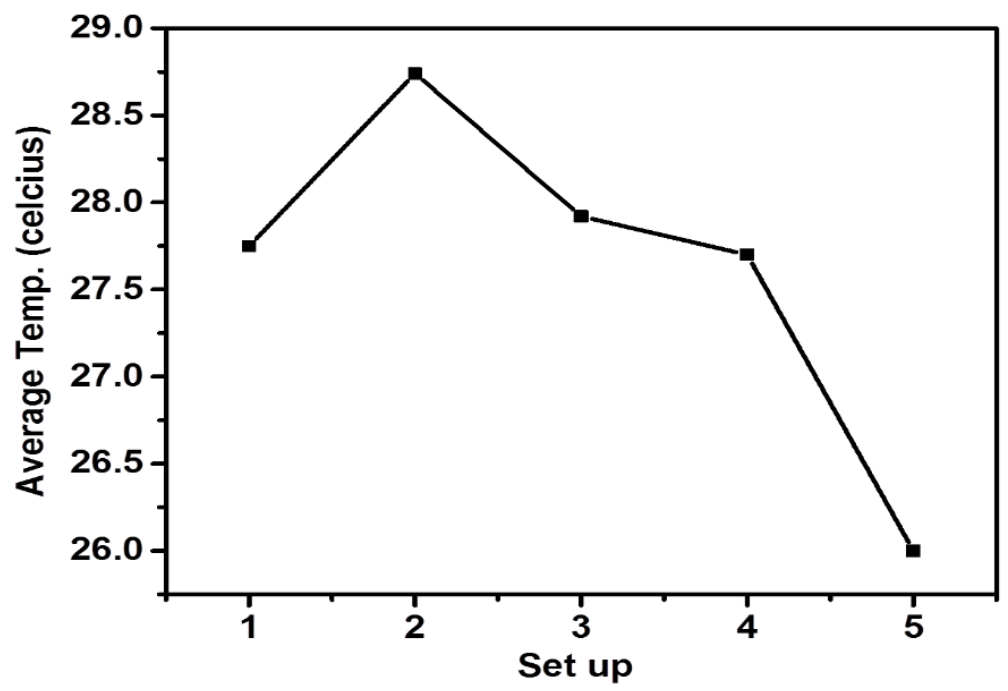

Figure 4 represents the average temperature per set up. 
Operating temperature is also a vital factor which determines the performance of the AD because it is an important condition for the survival and optimum flourishing of the microbial associates. Bacteria have two optimum range of temperature termed as mesophilic and thermophic temperature optimum. Anaerobic digesters have very good output efficiency while operated in the temperature range of $25-40{ }^{\circ} \mathrm{C}$. As shown in Figure 4 , the ambient temperature ranges from $26^{\circ} \mathrm{C}$ to $29^{\circ} \mathrm{C}$ was maintained throughout the experiment. According to Figure 4, all the setups were operated in the mesophilic temperature ranges.

\section{CONCLUSION}

In this study the local, simple, applicable and affordable method of generating Biogas has been explored. Among 5 different set -ups, a maximum gas produced from the mixture of cow dung plus poultry waste was achieved with set-up 2. The cumulative gas yielded from the mixture of cow dung plus poultry waste is $89 \mathrm{~cm}^{3}$, a $\sim 2, \sim 1.1, \sim 1.4$ and $\sim 1.6$-fold enhancement compared with set up 1,3,4 and 5, respectively. Therefore, 2:1 ratio was the optimum combination that produced the highest volume of Biogas. The optimum condition for higher efficiency has been achieved with $\mathrm{pH}$ values and temperature of 7.1-7.6 and $26^{\circ} \mathrm{C}-$ $29^{\circ} \mathrm{C}$, respectively. Thus, co-digestion of cow dung and poultry waste is a prime way of resolving the issue of inadequate feedstock for biogas production in Nigeria. It can be concluded that the percentage composition of Cow dung should be double than that of poultry waste when combining them for better biogas production.

\section{ACKNOWLEDGEMENT}

The authors wish to thank the efforts of the Mr. Rabiu Zakari and Mr. Adamu Ya'u from Physics and Chemistry laboratories of Federal University Dutse, Jigawa State - Nigeria, respectively, for their kind support and motivation in carrying out the experiments and results analysis.

\section{REFERENCES}

Abubakar, B.S.U and Ismail, N (2012). Anaerobic digestion of Cow Dung for Biogas production. Journal of Engineering and Applied Science, 7(2), 169-172

Ahmadu, T. (2009). Comparative Perfomance for Cow Dung and Chicken Droppings for Biogas Generation. Zaria: Amadu Bello University.

Alfa, I.M, Dahunsi, S.O, Iorhemen, O.T, Okafor, C.C and Ajayi, S.A. (2014). Comparative evaluation of biogas production from Poultry droppings, Cow dung and Lemon grass. Bioresource Technology,157, 270-277.

Dangogo, S. F. (1986). A simple biogas plant with additional gas storage System. Nigerian Journal of SolarEnergy, 5, 138-141.

Deublein, S. (2008). Biogas from Waste and Renewable Resources; An Introduction. Weiheim: Wiley-VCH.

Fasoyin, W. A. (2019). DEVELOPMENT OF A BIOGAS PLANT FROM COW DUNG, SWINE DUNG AND POULTRY DROPPING. International Journal of Advanced Research, 7(7), 816-822.

Fulford, D. (2011). Biogas Technology: Success Projects in Asia.

Hassan K. J., Z. M. (2015). Biogas Production Using Cow Dung, Poultry Waste and Yam Peels. International Journal of Environment and Bioenergy, 10(2), 107-114.

Iwayemi, A. (2008). Nigeria's Dual Energy Problems Policy Issues and Challenges being. 31st International Association for Energy Economics International Conference (pp. 18-20). Istanbul: Turkey.

Karki A. B., S. N. (2005, 04 01). Biogas as Renewable Energy Source in Nepal: Theory and Development. Kathmandu, Nepal, Nepal. 
Khana, S. (2008). Anaerobic Biotechnology for Bioenergy Production: Principle and Applications. Ames: Wiley Blackwell.

Maramba, R. S. (2011, 05 30). Biogas and Waste Recycling. Retrieved from Biogas Production: http://www.pcierd.dost.gov.ph/index.php/downloads/.../81-biogas-history

Mata-Alvarez, j. (2003). Biomethanization of the organic fraction of municipal solid waste,. IWA Publishing, London., 20.

Mshandete A.M, P. W. (2009). Biogas technology research in selected sub-saharan africa. African Journal of Biotechnology, 116-125.

Ocwieja, S. M. (2011, 05 17). Retrieved from http://www.cee.mtu.edu/peacecorps/studentfiles/Ocwieja-Uganda.pdf

Rahman, M., \& Muyeed, H. (2010). solid and hazardous watse management. Bangladesh: first ed. ITN-BUET,Dhaka.

Shrestha, A. (2010). Prospects of Biogas in Terms of Sco-Economic and Environmental. Napel: College of Applied Sciences-Nepal,Kathmandu.

Tatlidil, F. I. (2009). Farmers perception of sustainable agricultural and its determinants' A case study in Kahramanmaras province of Turkey. Environmental Development Sustainability Journal, 73-79.

Van Nes, W. \&. (2007, 07 04). Biogas for a better life: An African initiative. Renewable Energy World Magazine Vol. 10.

Venkata, R. P. (1991). Biogas programme in India. Mumbai: TIDE Publishers. 